\title{
Palaeogene diatomite deposits in Denmark: geological investigations and applied aspects
}

\author{
Stig A. Schack Pedersen
}

The Danish term 'moler' is the name for a special and unique marine deposit of Lower Eocene age found in the northern part of Denmark and the Danish North Sea. In the literature it is often referred to as mo-clay, the English translation of 'moler' - a whitish, powdery sediment that lithologically is a clayey diatomite. The deposit, which is defined as the Fur Formation, is also well known for its 180 volcanic ash beds, increasing in number towards the top of the formation (Pedersen \& Surlyk 1983). Due to Pleistocene glaciotectonic deformations the diatomite deposits crop out at the surface in the Limfjorden area (Gry 1940; Klint \& Pedersen 1995; Pedersen 1996, 2000). Prior to the deformations the Fur Formation was situated at about 50-100 m below sea level, but during the deformations the diatomite was displaced upwards into glaciotectonic complexes. The complexes form elongate parallel hills up to $80 \mathrm{~m}$ a.s.l. in the western Limfjord region (Fig. 1).

The clayey diatomite attracts attention because it is a valuable raw material for production of insulation bricks and absorbing granulates, which are mainly used as cat litter. In addition, the exposed Fur Formation is a unique reference for investigations of the Palaeogene stratigraphy in the North Sea, where mudstones and shales with ash layers are known as the Sele and Balder Formations (Schiøler et al. 2007). In a tectonic framework the ash layers provide a unique addition to the understanding of the development of the North Atlantic igneous province at the time when Greenland and Norway began to drift away from each other (Larsen $e t$ al. 2003). Moreover, the Fur Formation is especially noted for its rich fossil fauna, which comprises remarkably well-preserved specimens of birds, fish and insects. Due to the public interest two museum exhibitions have been established, on Mors and Fur, and the geological features are so evident that numerous geological field trips have benefited from the success of well-displayed geology seen in exposures along the coastal cliffs and in the mo-clay pits. At present a Norwegian drilling company is planning to use the Fur Formation outcrops at Skarrehage for testing before applying their new drilling method offshore. In 2007, GEUS has continued many years of mo-clay investigations, and this paper presents some results from the 2007 activities, in addition to a review on the geology of the mo-clay.

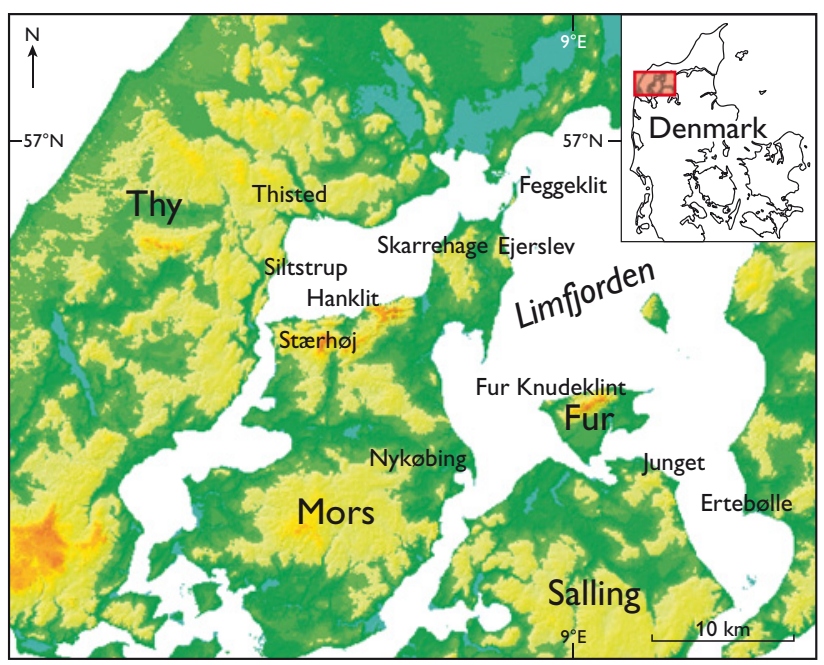

Fig. 1. Map of the western Limfjorden region with place names. Note the hilly landscapes on the islands of Mors and Fur.

\section{Sedimentology of the Fur Formation}

The Fur Formation is $c .60 \mathrm{~m}$ thick at the type locality in the north-west corner of the island of Fur. The sedimentology of the formation was described by Pedersen (1981) and Pedersen $\&$ Surlyk (1983), who demonstrated that parallel well-laminated intervals alternate with structureless intervals. Due to the exact identification and numbering of the ash layers the two sediment types can be followed throughout the diatomite basin. The laminated mo-clay formed during anoxic periods, whereas the structureless mo-clay represents oxic events, during which a rich bottom fauna inhabited the seabed. In many layers the ash grains fill the burrows facilitating the recognition of the trace fossils (Pedersen 1981).

Petrologically, diatom opal frustules make up $65 \%$ of the sediment. The dominant diatom is Coscinodiscus (Fig. 2). The clay content is about $28 \%$, but varies, and the clay fraction comprises the clay mineral smectite (Pedersen et al. 2004); the remainder is mainly disseminated pyrite. Mo-clay situated above the groundwater level has been depleted of pyrite, but mo-clay situated below the groundwater level shows a pyrite content that varies from 5 to $8 \%$. This gives the diatomite a black colour. Above the redox level the diatomite is light coloured due to the depletion of pyrite, which is corroded and transformed into sulphates (jarosite and gypsum) 

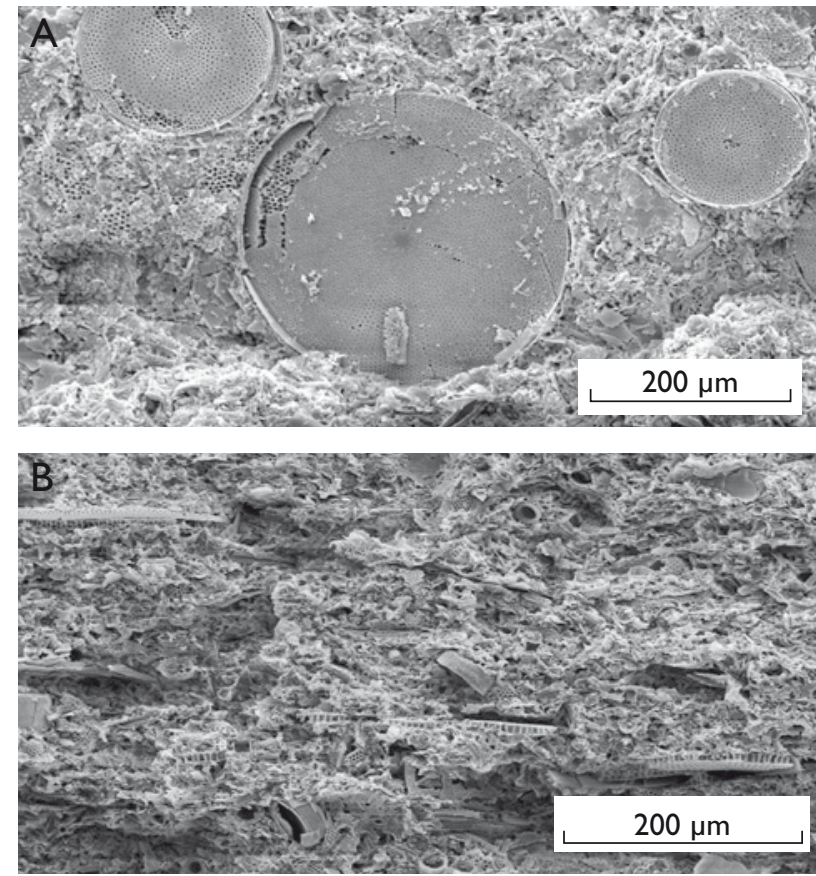

Fig. 2. Scanning electron microscope images of clayey diatomite from the Fur Formation. The upper image is a plan view, where the large diatom frustules of Coscinodiscus are seen. The lower image is perpendicular to the lamination and shows some diatom frustules in cross-section.

and limonite. Part of the latter is transported out to the slopes and cliffs at the coast, where it cements the Quaternary deposits, mainly the glaciofluvial sand and gravel, to form the so called 'red stone'.

During diagenesis amorphous opal $\mathrm{A}$ is transformed to microcrystalline opal $\mathrm{C} / \mathrm{T}$, and in the lower part of the formation cherty shales (skiferlag) have formed (Pedersen et al. 1998). In the middle and upper part of the formation calcareous concretions are seen. The concretions are found in about five marker levels, they are ellipsoid in shape and their size range from 0.3 to $0.75 \mathrm{~m}$ in thickness and one to a few metres in lateral extent. One exception is the calcareous concretion cementing the ash layer +101 , which is a $35 \mathrm{~cm}$ thick marker bed in the upper part of the formation. Gypsum is sometimes found as small rosettes up to $5 \mathrm{~cm}$ in size, often concentrated in glaciotectonic shear zones.

\section{Volcanic ash layers}

The volcanic ash layers were stratigraphically logged and numbered by Bøggild (1918), who also published the first data on the petrological composition and is responsible for the division of the ash layers into a negative and a positive series. From their geochemical characteristics, four stages of volcanic activity can be recognised (Pedersen et al. 1975).
Stage 1 corresponds to the ash layers from -39 to -22 , which vary in composition from rhyolitic to basaltic. The source of these ash layers was volcanic centres situated on the shelf west of the British Isles (Larsen et al. 2003). A volcanic stage pre-dating stage 1 is recorded from offshore Britain (Knox et al. 1997) and is probably responsible for the bentonite in the Holmehus Formation; it is well known that bentonite is a devitrification product of volcanic glass.

Stage 2 is represented by ash layers -21 to -15 , which are variable in composition and comprise phonolites, nephelinites, trachytes and rhyolites. The peralkaline nephelinitic ash layer -19 is a remarkable blue ash layer, easily recognisable, and the very distinct, $4 \mathrm{~cm}$ thick, orange coloured -17 is a diagenitically altered trachyte, formerly thought to be rhyolitic. The source of the stage 2 ash layers was either the shelf area west of the British Isles or the Gardiner igneous complex in East Greenland (Larsen et al. 2003).

Stage 3 is represented by the three distinctive black alkali basalt ash layers $-13,-12$ and -11 . The ash layers may originate from the opening rift between North-West Europe and Greenland (Larsen et al. 2003).

Stage 4 is the main tholeiitic basalt eruption, during which the positive numbered ash layers were formed. They correspond in composition to the basalts currently forming in Iceland. Thus the source could be regarded as a proto-Iceland situated in the middle of the incipient oceanic crust of the North Atlantic Ocean (Larsen et al. 2003). The most significant ash layer in this unit is the $20 \mathrm{~cm}$ grey rhyolitic andesite +19 , which has been dated to $54 \mathrm{Ma}$ (Larsen et al. 2003), and which is an important marker bed for the exploitation activities.

\section{Glaciotectonic deformation}

In the 1930s state-geologist H. Gry consulted the mo-clay companies, and from his co-operation with them he realised how important structural geology was for solving the exploration problems. In 1940 he summarised the structural knowledge of all the known outcrops of the Fur Formation and described their glaciotectonic framework (Gry 1940). Gry's model was monoglacial with a lobe-shaped body of ice advancing from the north. Pedersen (2000) demonstrated that the glaciotectonic structures were due to superimposed deformation. The Norwegian and Swedish advances spreading over the northern part of Denmark in the Weichselian at about 28-24 ka B.P. created the main structural features. However, evidence of older glaciations of Saalian age is also recorded, both as deposits (Hesselbjerg till and Harhøj sand series) and as minor deformations along the glaciotectonic unconformity truncating the Fur Formation (Fig. 3).

The advanced structural studies of the glaciotectonic complexes are based on the concept of thin-skinned thrust-fault 

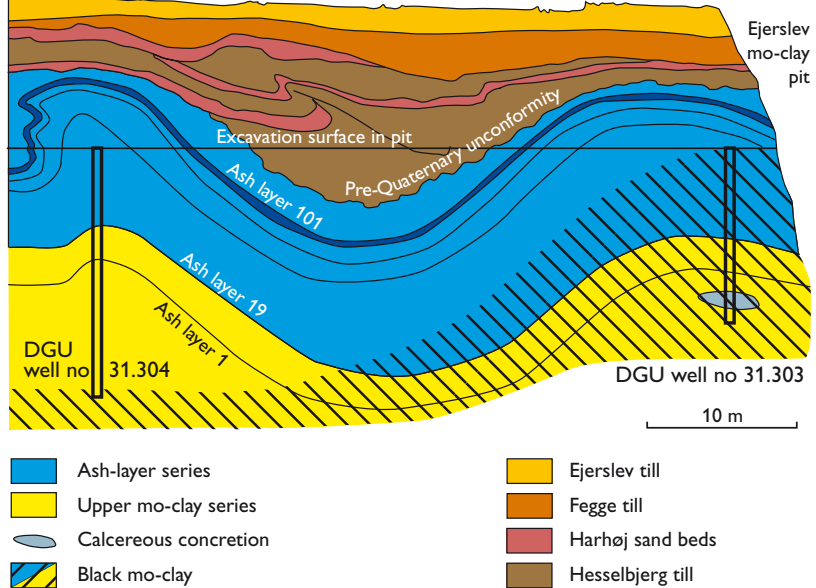

Fig. 3. Geological cross-section of the area with black diatomite. The location of the wells is shown in Fig. 4B (-303 and -304). The Hesselbjerg till and the Harhøj sand beds are of Saalian age, whereas the Fegge and Ejerslev tills represent, respectively, the Weichselian Norwegian and Swedish advances.

deformation and construction of balanced cross-sections. A prominent example of this is the Hanklit glaciotectonic complex, which constitutes three $60 \mathrm{~m}$ thick thrust sheets with a maximum displacement of about $300 \mathrm{~m}$ from the décollement surface at $80-100 \mathrm{~m}$ below sea level (Klint $\&$ Pedersen 1995). Before the displacement the upper surface of the Fur Formation was situated $20 \mathrm{~m}$ below sea level, from where it

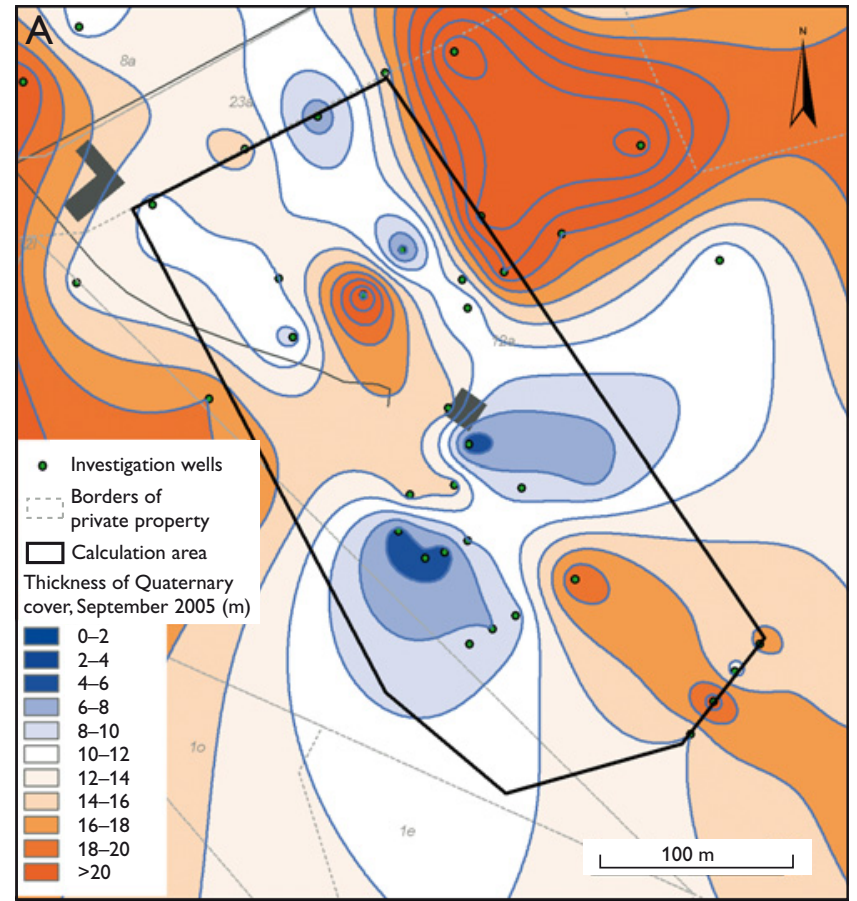

was displaced to $60 \mathrm{~m}$ above sea level to form the elongated E-W-trending hills of northern Mors (Fig. 1). A similar depth to the décollement surface (about $100 \mathrm{~m}$ b.s.l.) was calculated from area balance of the Feggeklit cross-section (Fig. 1). This study also demonstrated that the sequential deformations within a glaciotectonic propagation were related to one ice advance (Pedersen 1996). A number of advanced glaciotectonic studies are described in the series Danmarks og Grønlands Geologiske Undersøgelse Rapport from 1996 to 2007 , and document the structural framework of the areas planned for future excavation of the clayey diatomite.

\section{Raw material investigation}

In general all the mo-clay pits are located within elongate hanging-wall anticlines in thrust sheets of the Fur Formation. Thus the basic problem is to identify the trend of the anticlines in order to locate the boundaries of the excavation areas. When this has been solved, the important two questions to be answered are: How much diatomite is present, and how much cover has to be removed during the excavation?

The answers are provided by construction of isopach maps of the excavation areas and volume calculation with application of kriging (Cressie 1990). The data applied for the kriging are based on the information from the exploration wells (Fig. 4), where the depth to ash layer +19 is the most important parameter. The ash layers above +19 are included in the

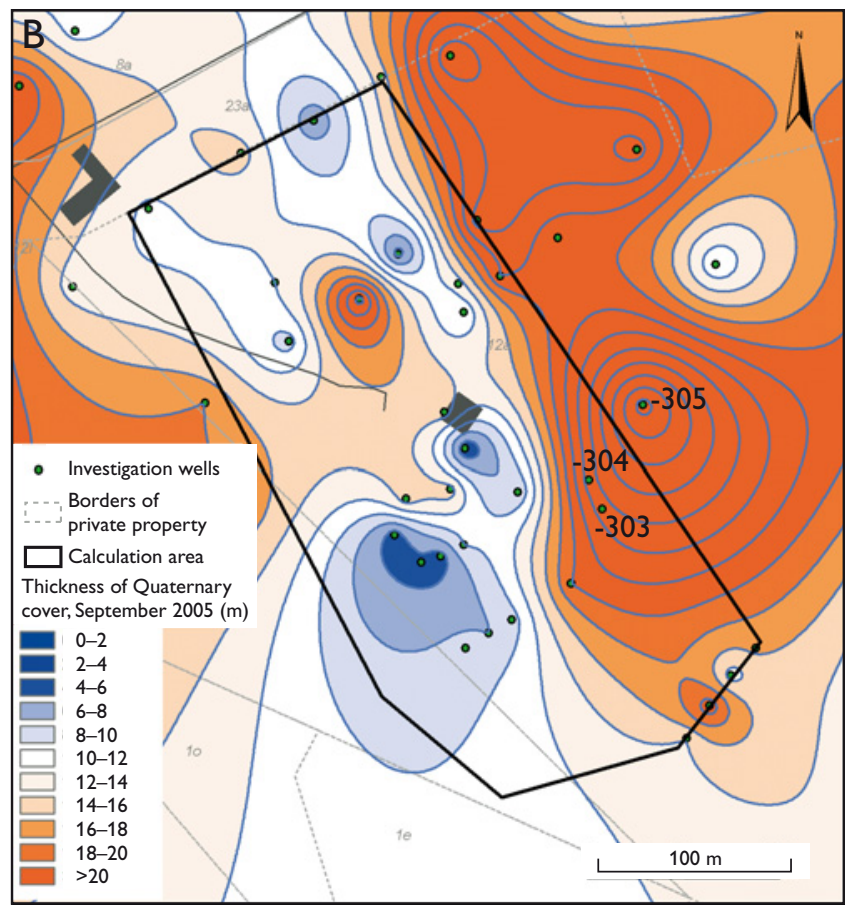

Fig. 4. Two isopach maps constructed by kriging calculation based on well data. A: Gives an unrealistic NE-trend of the raw material deposit. B: Improves the reliability of the isopach map by including data from the three new wells, $-303,-304$ and -305 , in the calculation. This map agrees well with the original structural model for the area. 


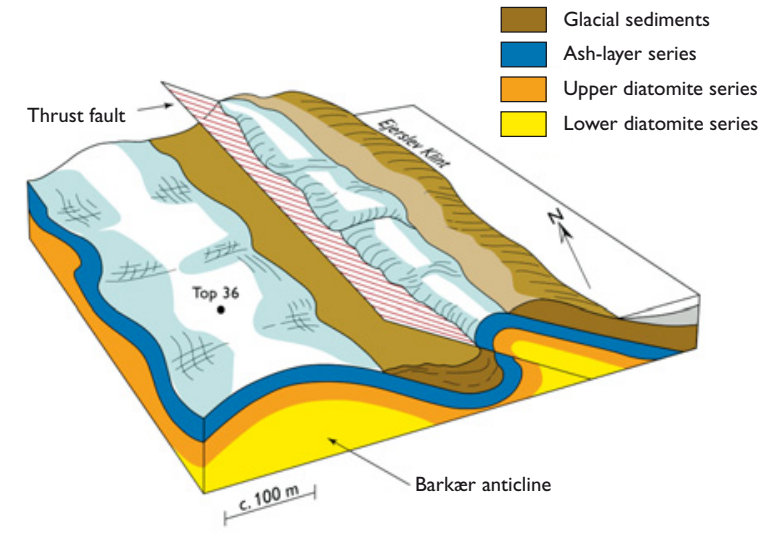

Fig. 5. Structural model for the northern part of the Ejerslev field. The Barkær anticline is the main target for exploitation. In the syncline east of the Barkær anticline, a more than $20 \mathrm{~m}$ thick sequence of Quaternary deposits is found, which makes this area uneconomic for excavation. Moreover, the diatomite here is probably also of a black variety unsuitable for production.

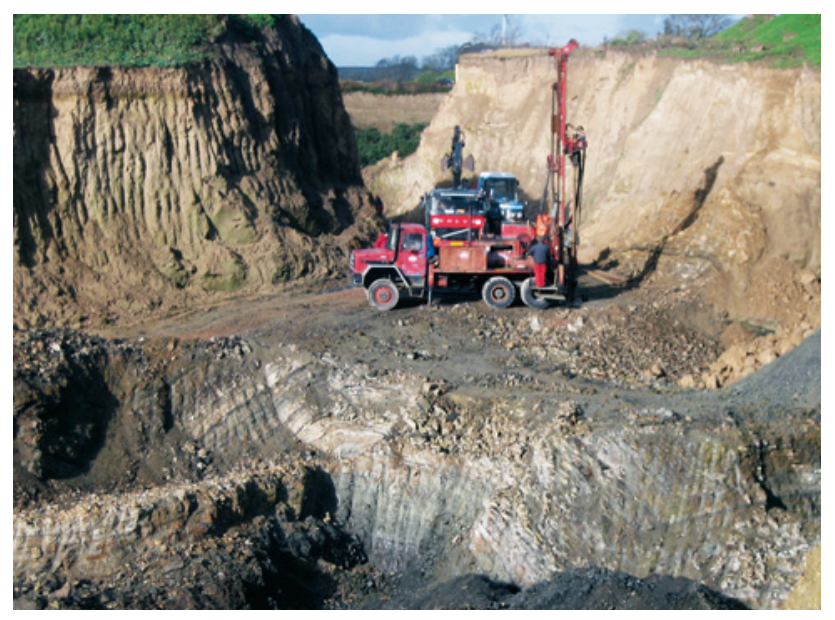

Fig. 6. Drill operation in the Ejerslev clay pit. The vehicles are parked on the top of the Barkær anticline (see Fig. 5), which is seen in front of the drill rig. Note the black colour of the diatomite, which is caused by a high content of disseminated pyrite. Till deposits occur behind and above the drill rig. Compare with Fig. 3.

unutilised cover, which is dominated by Quaternary deposits (Fig. 3). Only few and thin ash layers are found below ash layer +19 , and they do not affect the production. The lower boundary of the excavation is either at the groundwater level or at the occurrence of black diatomite, which usually coincide. However, exceptions occur as illustrated below.

The Ejerslev field is currently the main production area on Mors. For the production planning, an isopach map (Fig. 4A) was constructed in the spring of 2005 . However, the density of data points is crucial for the calculation of the exploitation area, and the resulting map contradicted the structural model for the area (Fig. 5). In the spring of 2007 an unusual occurrence of black diatomite cropped out during excavation of the uppermost part of the Fur Formation (Fig. 6). Based on three new wells, combined with field investigations, it was concluded that the black diatomite is preserved in an anticlinal structure (Fig. 3). Since the late Weichselian (c. $20 \mathrm{ka}$ ) this dome feature had been protected from percolating groundwater and no leaching of the pyrite had taken place. The subsequent kriging analysis had an important new data point in the most poorly covered area. The new isopach map (Fig. 4B) supports the original structural model for the area (Fig. 5) demonstrating the importance of using structural models.

\section{References}

Bøggild, O.B. 1918: Den vulkanske Aske i Moleret. Danmarks Geologiske Undersøgelse II. Række 33, 84 pp.

Cressie, N.A.C. 1990: The origins of kriging. Mathematical Geology 22, 239-252.

Gry, H. 1940: De istektoniske Forhold i Molerområdet. Meddelelser fra Dansk Geologisk Forening 9, 586-627.

Klint, K.E.S. \& Pedersen, S.A.S. 1995: The Hanklit glaciotectonic thrust fault complex, Mors, Denmark. Danmarks Geologiske Undersøgelse Serie A 35, 30 pp.

Knox, R.W.O’B., Holloway, S., Kirby, G.A. \& Bailey, H.E. 1997: Stratigraphic nomenclature of the UK North West Margin: 2. Early Paleogene lithostratigraphy and sequence stratigraphy, $58 \mathrm{pp}$. Nottingham: British Geological Survey.

Larsen, L.M., Godfrey Fitton, J. \& Pedersen, A.K. 2003: Paleogene volcanic ash layers in the Danish Basin: compositions and source areas in the North Atlantic Igneous Province. Lithos 71, 47-80.

Pedersen, A.K., Engell, J. \& Rønsbo, J.G. 1975: Early Tertiary volcanism in the Skagerrak: new chemical evidence from ash layers in the moclay of northern Denmark. Lithos 8, 255-268.

Pedersen, G.K. 1981: Anoxic events during sedimentation of a Palaeogene diatomite in Denmark. Sedimentology 28, 487-504.

Pedersen, G.K. \& Surlyk, F. 1983: The Fur Formation, a late Paleocene ash-bearing diatomite from northern Denmark. Bulletin of the Geological Society of Denmark 32, 43-65.

Pedersen, G.K., Pedersen S.A.S., Steffensen, J. \& Pedersen, C.S. 2004: Clay content of a clayey diatomite, the Early Eocene Fur Formation, Denmark. Bulletin of the Geological Society of Denmark 51, 159-177.

Pedersen, S.A.S. 1996: Progressive glaciotectonic deformation in Weichselian and Palaeogene deposits at Feggeklit, northern Denmark. Bulletin of the Geological Society of Denmark 42, 153-174.

Pedersen, S.A.S. 2000: Superimposed deformation in glaciotectonics. Bulletin of the Geological Society of Denmark 46, 125-144.

Pedersen, S.A.S., Lindgreen, H. \& Pedersen, G.K. 1998: Amorphous silica and hydrous aluminosilicates for production of construction materials. INCO-Copernicus project No. ERBIC15CT96 0712. Danmarks og Grønlands Geologiske Undersøgelse Rapport 1998/3, 47 pp.

Poul Schiøler et al. 2007: Lithostratigraphy of the Palaeogene - Lower Neogene succession of the Danish North Sea. Geological Survey of Denmark and Greenland Bulletin 12, 77 pp. 